\title{
Time to re-think the use of dobutamine in sepsis
}

\author{
Ryota Sato ${ }^{1,2^{*}}$ and Michitaka Nasu ${ }^{1}$
}

\begin{abstract}
Dobutamine is commonly used worldwide and included in the protocol for early goal-directed therapy (EGDT). Since the use of dobutamine in EGDT was reported, it has been considered to be an important component, especially in the treatment of septic patients with myocardial dysfunction. However, it is questionable whether dobutamine improves the mortality of sepsis and septic shock.

In three recent randomized controlled trials (ProCESS, ProMISe, and ARISE trials), the frequency of dobutamine use was significantly higher in the EGDT group than in the standard care group, but there were no significant differences in the mortality between the groups. These results suggested that dobutamine use may have been overemphasized despite its insignificant effect on the mortality in septic patients. Further, a propensity score analysis revealed that dobutamine use was associated with higher mortality in patients with septic shock.

Although dobutamine leads to an increase in cardiac index, myocardial oxygen demand also increases, thus increasing the risk of myocardial ischemia and tachyarrhythmia. It is well known that the mortality in sepsis complicated with atrial fibrillation (AFib) is worse than that in sepsis without AFib. A propensity score-matched analysis reported that $\beta$-blockers were associated with better survival in patients with sepsis complicated with AFib. Further, a randomized controlled trial reported that a short-acting $\beta$-blocker improved the survival in patients with septic shock. These studies also indicated the risk of $\beta$-stimulation during sepsis.

Notably, improvements in surrogate markers, such as $\mathrm{Cl}$, do not always indicate improvements in patient-centered outcomes, such as mortality. Conversely, some evidence indicates the worsening of patient-centered outcomes despite improvements in surrogate markers.

Thus, available evidence suggests that the benefits of dobutamine in patients with sepsis are unclear, but its use might be harmful rather than beneficial, considering the beneficial effects of $\beta$-blockers in sepsis that have been reported in recent clinical studies. From this perspective, we will soon have to rethink regarding dobutamine use in patients with sepsis.
\end{abstract}

Keywords: Sepsis, Septic shock, Dobutamine, Inotropes, Sepsis induced cardiomyopathy, Septic cardiomyopathy

\section{Manuscript}

Dobutamine is a synthetic catecholamine that acts on $\alpha-1, \beta-1$, and $\beta-2$ adrenergic receptors. It is commonly used worldwide and included in the protocol for early goal-directed therapy (EGDT) [1]. Since the use of dobutamine in EGDT was reported, it has been considered to be an important component, especially in the treatment of septic patients with myocardial dysfunction. Currently, surviving sepsis campaign guidelines suggest

\footnotetext{
*Correspondence: st051035@gmail.com

'Department of Emergency and Critical Care Medicine, Urasoe General Hospital, Okinawa, Japan

${ }^{2}$ Department of Internal Medicine, John A. Burns School of Medicine, University of Hawaii at Manoa, 1356 Lusitana Street, 7th Floor, Honolulu, HI 96813, USA
}

(c) The Author(s). 2017 Open Access This article is distributed under the terms of the Creative Commons Attribution 4.0 International License (http://creativecommons.org/licenses/by/4.0/), which permits unrestricted use, distribution, and reproduction in any medium, provided you give appropriate credit to the original author(s) and the source, provide a link to the Creative Commons license, and indicate if changes were made. The Creative Commons Public Domain Dedication waiver (http://creativecommons.org/publicdomain/zero/1.0/) applies to the data made available in this article, unless otherwise stated.

the use of dobutamine in the presence of myocardial dysfunction indicated by elevated cardiac filling pressures and low cardiac output or ongoing signs of hypoperfusion, despite achieving adequate intravascular volume and mean arterial pressure [2]. However, it is questionable whether dobutamine improves the mortality of sepsis and septic shock.

The results of three randomized controlled trials (ProCESS, ProMISe, and ARISE trials) on resuscitation in sepsis have been recently published [3-5]. In these trials, the frequency of dobutamine use was significantly higher in the EGDT group than in the standard care group (ProCESS trial 8.0 vs. $1.1 \%$, respectively; $p<0.001$; ProMISe trial 8.0 vs. $1.1 \%$, respectively; $p<0.001$; and ARISE trial 15.4 vs. $2.6 \%$, respectively; $p<0.0001$ ), but 
there were no significant differences in the mortality between the groups. Although recent meta-analysis of randomized trials suggested inodilators such as levosimendan and dobutamine might improve the survival in septic patients [6], most studies comparing inotropes included in this study were small single center studies, and we have to be careful to interpret the results. Furthermore, the biggest randomized controlled trial showed no benefit of levosimendan in mortality or prevention for organ dysfunction in septic patients [7]. These results suggested that use of inotropes may have been overemphasized despite its insignificant effect on the mortality in patients with sepsis. Further, a propensity score analysis revealed that dobutamine use was associated with higher mortality in patients with septic shock [8].

Conversely, in patients with low cardiac index (CI), the benefit of dobutamine use continues to be unclear. Vieillard-Baron et al. reported simultaneous Doppler echocardiographic measurement of $\mathrm{CI}$ and left ventricular ejection fraction (LVEF) in patients with septic shock and estimated the association between them using the following formula: $\mathrm{CI}=(0.05 \times \mathrm{LVEF})+0.73$ [9]. According to this formula, LVEF of $35 \%$ is associated with a CI of 2.5 , which is the lower threshold of the normal CI range. Because maintaining supranormal $\mathrm{CI}$ using dobutamine is not associated with better survival [10], LVEF of $35 \%$, but not $<35 \%$, may be sufficient, and a relatively low LVEF (35-50\%) may not be associated with mortality. The population with LVEF $<35 \%(\mathrm{CI}<2.5)$ represents a small percentage of patients with septic shock and may be more likely to benefit from dobutamine use. However, a meta-analysis reported that dobutamine did not improve the mortality in patients with severe heart failure, both in outpatient and inpatient settings [11]. In this study, mean CI ranged from 1.7 to 2.5 and mean LVEF from 20 to $35 \%$, suggesting that dobutamine use may not be effective even in patients with low CI. Since $\beta-1$ receptor is known to be downregulated in patients with heart failure [12], we have to be careful to interpret this result. However, even among septic patients, myocardial adrenergic responsiveness is considered to be depressed [13]. Therefore, the use of dobutamine in septic patients may not be effective as well as patients with severe heart failure.

Further, previous randomized control trials reported that maintaining higher $\mathrm{CI}$ than normal with dobutamine did not affect mortality while dobutamine successfully elevated CI even in patients with normal CI [10, 14]. Although dobutamine leads to an increase in $\mathrm{CI}$ and splanchnic blood flow [15], myocardial oxygen demand also increases, thus increasing the risk of myocardial ischemia and tachyarrhythmia [16]. It is well known that the mortality in sepsis complicated with atrial fibrillation (AFib) is worse than that in sepsis without AFib [17]. A propensity score-matched analysis reported that $\beta$-blockers were associated with better survival in patients with sepsis complicated with AFib [18]. Further, a randomized controlled trial reported that a short-acting $\beta$-blocker improved the survival in patients with septic shock [19]. These studies also indicated the risk of $\beta$-stimulation during sepsis.

Notably, improvements in surrogate markers, such as $\mathrm{CI}$, do not always indicate improvements in patientcentered outcomes, such as mortality. Conversely, some evidence indicates the worsening of patient-centered outcomes despite improvements in surrogate markers.

Thus, available evidence suggests that the benefits of dobutamine in patients with sepsis are unclear, but its use might be harmful rather than beneficial, considering the beneficial effects of $\beta$-blockers in sepsis that have been reported in recent clinical studies. From this perspective, we will soon have to rethink regarding dobutamine use in patients with sepsis.

\section{Abbreviations \\ AFib: Atrial fibrillation; Cl: Cardiac index; EGDT: Early goal-directed therapy; LVEF: Left ventricular ejection fraction}

\section{Acknowledgements \\ Not applicable \\ Funding \\ None \\ Availability of data and materials \\ Not applicable.}

\section{Authors' contributions}

RS was responsible for conception of the letter and drafted and revised the manuscript. MN helped to draft the manuscript. Both authors read and approved the final manuscript.

\section{Authors' information}

RS is a Japanese board-certified emergency physician. MN is a Japanese board-certified emergency and critical care physician.

Ethical approval and consent to participate

Not applicable

Consent for publication

Not applicable

\section{Competing interests}

The authors declare that they have no competing interests.

\section{Publisher's Note}

Springer Nature remains neutral with regard to jurisdictional claims in published maps and institutional affiliations.

Received: 23 October 2017 Accepted: 17 November 2017

Published online: 21 November 2017

\section{References}

1. Rivers E, Nguyen B, Havstad S, Ressler J, Muzzin A, Knoblich B, et al. Early goal-directed therapy in the treatment of severe sepsis and septic shock. N Engl J Med. 2001;345(19):1368-77.

2. Rhodes A, Evans LE, Alhazzani W, Levy MM, Antonelli M, Ferrer R, et al. Surviving sepsis campaign: international guidelines for management of sepsis and septic shock: 2016. Intensive Care Med. 2017;43(3):304-77. 
3. Investigators PCESS, Yealy DM, Kellum JA, Huang DT, Barnato AE, Weissfeld $L A$, et al. A randomized trial of protocol-based care for early septic shock. N Engl J Med. 2014;370(18):1683-93.

4. Mouncey PR, Osborn TM, Power GS, Harrison DA, Sadique MZ, Grieve RD, et al. Trial of early, goal-directed resuscitation for septic shock. N Engl J Med. 2015;372(14):1301-11.

5. Investigators ARISE, ANZICS Clinical Trial Group, Peake SL, Delaney A, Balley M, Bellomo R, Cameron PA, et al. Early goal-directed therapy in the treatment of severe sepsis and septic shock. N Engl J Med. 2014;371(16): 1496-506.

6. Belletti A, Benedetto U, Biondi-Zoccai G, Leggieri C, Silvani P, Angelini GD, et al. The effect of vasoactive drugs on mortality in patients wuth severe sepsis and septic shock. A network meta-analysis of randomized trials. J Crit Care. 2017;37:91-8.

7. Gordon AC, Perkins GD, Singer M, McAuley DF, Orme RM, Santhakumaran S, et al. Levosimendan for the prevention of acute organ dysfunction in sepsis. N Engl J Med. 2016;375(17):1638-48.

8. Wilkman E, Kaukonen KM, Pettilä V, Kuitunen A, Varpula M. Association between inotrope treatment and 90-day mortality in patients with septic shock. Acta Anaesthesiol Scand. 2013;57(4):431-42.

9. Vieillard-Baron A, Prin S, Chergui K, Dubourg O, Jardin F. Hemodynamic instability in sepsis: bedside assessment by Doppler echocardiography. Am J Respir Crit Care Med. 2003;168(11):1270-6

10. Hayes MA, Timmins AC, Yau EH, Palazzo M, Hinds CJ, Watson D. Elevation of systemic oxygen delivery in the treatment of critically ill patients. N Engl J Med. 1994;330(24):1717-22.

11. Tacon CL, McCaffrey J, Delaney A. Dobutamine for patients with severe heart failure: a systematic review and meta-analysis of randomized controlled trials. Intensive Care Med. 2012;38(3):359-67.

12. Bristow MR, Ginsburg R, Minobe W, Cubicciotti RS, Sageman WS, Lurie K, et al. Decreased catecholamine sensitivity and beta-adrenergic receptor density in falling human hearts. N Engl J Med. 1982;307(4):205-11.

13. Cariou A, Pinsky MR, Monchi M, Laurent I, Vinsonneau C, Chiche JD, et al. Is myocardial adrenergic responsiveness depressed in human septic shock? Intensive Care Med. 2008:34(5):917-22.

14. Gattinoni L, Brazzi L, Pelosi P, Latini R, Tognoni G, Pesenti A, et al. A trial of goal-oriented hemodynamic therapy in critically ill patients. SvO2 Collaborative Group. N Engl J Med. 1995;333(16):1025-32.

15. Reyad AR, Elkharboutly W, Wahba A, Elmorshedi M, Hasaneen NA. Effect of intraoperative dobutamine on splanchnic tissue perfusion and outcome after Whipple surgery. J Crit Care. 2013;28(4):531.e7-15.

16. Triposkiadis F, Parissis JT, Starling RC, Skoularigis J, Louridas G. Current drugs and medical treatment algorithms in the management of acute decompensated heart failure. Expert Opin Investig Drugs. 2009:18(6):695-707.

17. Kuipers S, Klein Kouwenberg PM, Cremer OL. Incidence, risk factors and outcomes of new-onset atrial fibrillation in patients with sepsis: a systematic review. Crit Care. 2014;18(6):688.

18. Walkey AJ, Evans SR, Winter MR, Benjamin EJ. Practice patterns and outcomes of treatments for atrial fibrillation during sepsis: a propensitymatched cohort study. Chest. 2016;149(1):74-83.

19. Morelli A, Ertmer C, Westphai M, Rehberg S, Kampmeier T, Ligges S, et al. Effect of heart rate control with esmolol on hemodynamic and clinical outcomes in patients with septic shock: a randomized clinical trial. JAMA. 2013;310(16):1683-91.

\section{Submit your next manuscript to BioMed Central and we will help you at every step:}

- We accept pre-submission inquiries

- Our selector tool helps you to find the most relevant journal

- We provide round the clock customer support

- Convenient online submission

- Thorough peer review

- Inclusion in PubMed and all major indexing services

- Maximum visibility for your research

Submit your manuscript at www.biomedcentral.com/submit
) Biomed Central 